\title{
CHEMOMETRIC APPROACH FOR THE DEVELOPMENT, OPTIMIZATION AND VALIDATION OF HILIC METHODS USED FOR THE DETERMINATION OF ALKALOIDS FROM POPPY STRAW
}

\author{
Jelena Acevska ${ }^{1 *}$, Gjoshe Stefkov $^{2}$, Natalija Nakov ${ }^{1}$, Rumenka Petkovska $^{1}$, Liljana Ugrinova $^{1}$, \\ Svetlana Kulevanova ${ }^{2}$, Aneta Dimitrovska ${ }^{1}$ \\ ${ }^{1}$ Institute of Applied Chemistry and Pharmaceutical Analysis \\ ${ }^{2}$ Institute of Pharmacognosy \\ Faculty of Pharmacy, University Ss. Cyril and Methodius, Majka Tereza 47, 1000 Skopje, \\ Republic of Macedonia \\ jelena_petrusevska@ff.ukim.edu.mk
}

Two hydrophilic interaction liquid chromatography (HILIC) methods for simultaneous determination of the major alkaloids (morphine, codeine, thebaine, oripavine, papaverine and noscapine) present in opium poppy straw (Papaver somniferum L., Papaveraceae) were developed. The chromatographic behavior of the target alkaloids was investigated on two different HILIC stationary phases (bare silica, SiHILIC; zwitterionic, ZIC-HILIC) and systematic optimization carried out using chemometrics. A full factorial design of the experiments was utilized to assess the influence of acetonitrile content, ionic strength and $\mathrm{pH}$ of the mobile phase buffer on the critical resolutions and relevant retention factors. Central composite circumscribed design of experiments was used for robustness testing during method validation. The separation of alkaloids was obtained within a close retention window on both columns with optimized gradient elution, though the ZIC-HILIC method had advantages over Si-HILIC method in terms of sensitivity, robustness and cost. This method was found suitable for the determination of the morphinan alkaloids in poppy straw.

Keywords: chemometry; design of experiments; HILIC/DAD; opium poppy alkaloids

\section{ХЕМОМЕТРИСКИ ПРИСТАП ЗА РАЗВОЈ, ОПТИМИЗАЦИЈА И ВАЛИДАЦИЈА НА НILIC-МЕТОДИ ЗА ОПРЕДЕЛУВАЊЕ АЛКАЛОИДИ ОД АФИОНОВИ ЧУШКИ}

Развиени се две методи за едновремено определување на главните алкалоиди (морфин, кодеин, тебаин, орипавин, папаверин и носкапин) од афион (Papaver somniferum L., Papaveraceae) со примена на течна хроматографија со хидрофилна интеракција (HILIC).

Хроматографското однесување на целните алкалоиди е испитувано на две различни стационарни фази за течна хроматографија со хидрофилна интеракција: необработена силика (SiHILIC) и цвитерјонска стационарна фаза (ZIC-HILIC).

Влијанието на хроматографските фактори (содржина на ацетонитрил, јонска јачина и $\mathrm{pH}$ вредност на пуферот во составот на мобилната фаза) врз неколку хроматографски параметри е проценето со примена на факторски дизајн на експериментите. Квадратен модел од трет ред (Central Composite Circumscribed Design of Experiments) е користен за утврдување на робусноста во рамките на валидацијата на методите.

Разделувањето на алкалоидите е постигнато во двете колони со оптимизирано градиентно елуирање. Методот ZIC-HILIC има предност пред методот Si-HILIC во однос на сензитивност, робусност и цена. Овој метод е погоден за определување на морфинските алкалоиди од афионови чушки.

Клучни зборови: хемометрија; дизајн на експерименти; HILIC/DAD; опиумски алкалоиди од афион 


\section{INTRODUCTION}

Opium poppy (Papaver somniferum L., Papaveraceae) is grown in the Republic of Macedonia for pharmaceutical and food purposes. The excessive and continuously growing need for natural opium poppy alkaloids as a source of therapeutic agents [1] necessitates the development and optimization of convenient high-throughput methods for qualitative and quantitative profiling of alkaloids in poppy straw.

High performance liquid chromatography (HPLC) is an efficient technique for the separation and quantification of opium alkaloids [2-11]. Due to the large polarity range of the major opium alkaloids, most applications use RP-HPLC with gradient elution and ion-pairing agents. Such methods can be very sensitive to minor changes in chromatographic conditions, prolonging the analysis and shortening column life [10]. Ion-pairing agents can be avoided by employing a high $\mathrm{pH}$ mobile phase. Our previous work indicates good separation of the major alkaloids is achieved using a triethylamine/trifluoracetic acid (in water) buffer at pH 9.6 [12, 13].

Hydrophilic interaction liquid chromatography (HILIC) is an alternative method for separating polar components [14], which could be used for the separation of opium alkaloids. Moreover, due to the large differences between alkaloid polarities, the amphoteric properties and/or limited water solubility of some of the alkaloids, employing a column with zwitterionic characteristics may assist in separation. Zwitterionic separation materials are characterized by carrying both positive and negative charges on the surface, where the functional moieties contain two oppositely charged groups in close proximity at a stoichiometric ratio, the electrostatic interaction between the charged groups on the stationary phase and oppositelycharged analytes is weaker compared to normal ion exchangers. Zwitterionic phases have also been found suitable for HILIC due to their highly hydrophilic surface layer [15]. The use of a mobile phase high organic solvent content is compatible with mass spectrometer detection (due to increased ionization and sensitivity), which offer additional advantage of HILIC methods [16, 17].

Modern method development trends are aiming towards rationalizing the extensive and expensive laboratory work, as well as efficient data processing. The design of experiments (DoE) approach maximizes the utilization of data from previously planned experiments with the help of mathematical criteria included in the factorial design, which allows for the prediction of optimal values for experimental factors. Response Surface Methodology (RSM) is used to optimize experimental values for important experimental factors [18-25].

Previously published GC/FID/MS and RPHPLC/DAD methods [12, 13] indicated separation of the major alkaloids is achieved within $10 \mathrm{~min}$. As GC uses equipment which may not be at the disposal of every laboratory, and that gradient elution is required for HPLC method, further research was conducted to develop an alternative HILIC method for the separation of opium poppy alkaloids using common HPLC equipment. DoE was employed for the development, systematic optimization and robustness testing of two HILIC methods using bare silica (Si-HILIC) and zwitterionic (ZIC-HILIC) stationary phases. These methods are used for the determination of the morphinan alkaloids from poppy straw of improved Papaver strains.

\section{EXPERIMENTAL}

\subsection{Materials}

Free-base morphine (MO), codeine (CD), oripavine (OR), thebaine (TB), noscapine (NS), papaverine $(\mathrm{PV})$, and samples from poppy straw were obtained from Alkaloid A.D., Skopje (Skopje, R. Macedonia).

\subsection{Reagents}

Acetonitrile (ACN, HPLC grade) and acetic acid (for synthesis) were purchased from Merck (Darmstadt, Germany). Ammonium acetate (pro analysis) and ammonium formate (pro analysis) were purchased from Fluka (Steinheim, Germany). Water (highly purified) was obtained from a TKALAB Reinstwasser system (Niederelbert, Germany).

\subsection{Standard solution of alkaloids}

Stock solutions of $2 \mathrm{mg} / \mathrm{ml} \mathrm{MO}, 1 \mathrm{mg} / \mathrm{ml}$ $\mathrm{CD}, 1 \mathrm{mg} / \mathrm{ml} \mathrm{TB}, 1 \mathrm{mg} / \mathrm{ml} \mathrm{OR}, 1 \mathrm{mg} / \mathrm{ml} \mathrm{PV}$ and $2 \mathrm{mg} / \mathrm{ml} \mathrm{NS}$ were diluted in ACN to obtain standard alkaloid solutions at concentrations of $200 \mu \mathrm{g} / \mathrm{ml} \mathrm{MO}, 100 \mu \mathrm{g} / \mathrm{ml} \mathrm{CD}$ and NS and $50 \mu \mathrm{g} / \mathrm{ml}$ $\mathrm{TB}, \mathrm{PV}$ and $\mathrm{OR}$.

\subsection{Sample preparation}

Mature poppy capsules and poppy capsule stems (up to $10 \mathrm{~cm}$ length) were collected, threshed to remove the seeds and $0.1 \mathrm{~g}$ of the dry, pulverized poppy straw (mesh No. $45,0.385 \mathrm{~mm}$ ) extracted with $5 \mathrm{ml}$ methanol by ultrasonic agita- 
tion $(40 \mathrm{kHz})$ for $20 \mathrm{~min}$ at $40^{\circ} \mathrm{C}$. The extract was centrifuged, the supernatant filtered and collected. The remaining solid was extracted with an additional $5 \mathrm{ml}$ methanol, the filtrates combined and diluted to $10.0 \mathrm{ml}$ with methanol. After filtration through a $0.45 \mu \mathrm{m}$ Millipore filter, the samples were analyzed using HPLC.

\subsection{Chemometrics}

DoE was used to assess the influence of ACN content, ionic strength and the $\mathrm{pH}$ of the mobile phase buffer on chromatographic responses $\left(2^{3}\right.$ FFL DoE), for determining the $\mathrm{pH}$ profile of the components in the mixture $\left(2^{2} \mathrm{CCC} \mathrm{DoE}\right)$ and for the robustness testing during method validation $\left(2^{3}\right.$ CCC DoE). The $2^{3}$ FFL DoE required $2^{k}+n$ experiments and the CCC DoE required $2^{k}+2 k+n$ experiments, where $k$ was the number of parameters studied and $n$ was the number of central points included $(n=3)$. Three repetitions at the central points are required to determine the experimental error variance and test the predictive validity of the model [21].
The experimental plans for conducting the DoEs are shown in Tables 1-3.

Table 1

Experimental plan for conducting $2^{3}$ FFL DoE

\begin{tabular}{ccccccccccccc}
\hline \hline \multicolumn{11}{c}{ Experiment No* } \\
\hline Factors & 1 & 2 & 3 & 4 & 5 & 6 & 7 & 8 & 9 & 10 & 11 \\
$x_{1}$ & - & + & - & + & - & + & - & + & 0 & 0 & 0 \\
$x_{2}$ & - & - & + & + & - & - & + & + & 0 & 0 & 0 \\
$x_{3}$ & - & - & - & - & + & + & + & + & 0 & 0 & 0 \\
\hline \hline
\end{tabular}

*Defining the experimental factor $(x)$ values at low (-), central (0) and high (+) level.

Table 2

Experimental plan for conducting $2^{2}$ CCC DoE

\begin{tabular}{cccccccccccc}
\hline \hline \multicolumn{11}{c}{ Experiment No* } \\
\hline Factors & 1 & 2 & 3 & 4 & 5 & 6 & 7 & 8 & 9 & 10 & 11 \\
$x_{1}$ & - & + & - & + & - & + & 0 & 0 & 0 & 0 & 0 \\
$x_{2}$ & - & - & + & + & 0 & 0 & - & + & 0 & 0 & 0 \\
\hline \hline
\end{tabular}

*Defining the experimental factor (x) values at low (-), central (0) and high (+) level.

Table 3

Experimental plan for conducting $2^{3}$ CCC DoE

\begin{tabular}{cccccccccccccccccc}
\hline \hline & \multicolumn{11}{c}{ Experiment $\mathrm{No}^{*}$} \\
\hline Factors & 1 & 2 & 3 & 4 & 5 & 6 & 7 & 8 & 9 & 10 & 11 & 12 & 13 & 14 & 15 & 16 & 17 \\
$x_{1}$ & - & + & - & + & - & + & - & + & - & + & 0 & 0 & 0 & 0 & 0 & 0 & 0 \\
$x_{2}$ & - & - & + & + & - & - & + & + & 0 & 0 & - & + & 0 & 0 & 0 & 0 & 0 \\
$x_{3}$ & - & - & - & - & + & + & + & + & 0 & 0 & 0 & 0 & - & + & 0 & 0 & 0 \\
\hline \hline
\end{tabular}

*Defining the experimental factor $(x)$ values at low (-), central (0) and high (+) level.

The significance of the factors was assessed by calculating the factorial coefficients $(b)$ of the corresponding polynomial given in equations (1) for the $2^{3}$ FFL DoE, (2) for the $2^{2}$ CCC DoE and (3) for the $2^{3}$ CCC DoE:

$$
\begin{aligned}
& y=b_{0}+b_{1} x_{1}+b_{2} x_{2}+b_{3} x_{3}+b_{12} x_{1} x_{2}+b_{13} x_{1} x_{3}+b_{23} x_{2} x_{3} \\
& y=b_{0}+b_{1} x_{1}+b_{2} x_{2}+b_{11} x_{1} x_{1}+b_{22} x_{2} x_{2}+b_{12} x_{1} x_{2} \\
& y=b_{0}+b_{1} x_{1}+b_{2} x_{2}+b_{3} x_{3}+b_{11} x_{1} x_{1}+b_{22} x_{2} x_{2}+b_{33} x_{3} x_{3} \\
& +b_{12} x_{1} x_{2}+b_{13} x_{1} x_{3}+b_{23} x_{2} x_{3}+b_{123} x_{1} x_{2} x_{3}
\end{aligned}
$$

where $x$ was the experimental factor, $y$ represented the estimated response, $b_{o}$ was the average experimental response, coefficients $b_{1}, b_{2}$ and $b_{3}$ were the estimated effects of the factors and the coefficients $b_{12}, b_{13}, b_{23}$ and $b_{123}$ were the interaction terms.

MODDE 8.0 Software (Umetrics, Umea, Sweden) was used for the optimization of experimental factors through an appropriate factorial design (26). The designed experiments were conducted using a standard solution of alkaloids with isocratic elution.

\subsection{Chromatographic conditions}

Method development was performed on Agilent 1200 HPLC/DAD system.

Si-HILIC was performed using a Lichrospher Hibar Si column $(250 \mathrm{~mm} \times 4.6 \mathrm{~mm}$ i.d., $5 \mu \mathrm{m}$ particle size, Merck). The mobile phase was $125 \mathrm{mM}$ ammonium acetate in water, $\mathrm{pH}$ adjusted to 4.5 using acetic acid (Solvent A) and ACN (Solvent B), filtered through $0.45 \mu \mathrm{m}$ Millipore filters. The separation of the six alkaloids was achieved with gradient elution: $0-1$ min $95 \%$ solvent $\mathrm{B}$ and 1.1-8 min $85 \%$ solvent B (followed by an equilibration step: $8.1-30 \mathrm{~min}, 95 \%$ solvent B), a flow rate of $2.0 \mathrm{ml} / \mathrm{min}$ and $20 \mu 1$ injection volume. The column was maintained at $30^{\circ} \mathrm{C}$ and detection was carried out at $280 \mathrm{~nm}$.

ZIC-HILIC was performed on a SeQuant ${ }^{\circledR}$ ZIC $^{\circledR}$-HILIC column $(150 \mathrm{~mm} \times 4.6 \mathrm{~mm}$ i.d., $5 \mu \mathrm{m}$ particle size, $200 \AA$ pore size, Merck) and alkaloid 
separation was achieved by gradient elution with $10 \mathrm{mM}$ ammonium formate in water, $\mathrm{pH}$-adjusted to 4.0 using formic acid (Solvent A) and ACN (Solvent B) as a mobile phase (filtered through $0.45 \mu \mathrm{m}$ Millipore filters). The separation of the six alkaloids was achieved with gradient elution: 0-2 min 95\% solvent B and 2.1-10 min $80 \%$ solvent $\mathrm{B}$ (followed by an equilibration step: 10.1-30 $\min 95 \%$ solvent $\mathrm{B}$ ), a flow rate of $1.0 \mathrm{ml} / \mathrm{min}$ and a $20 \mu 1$ injection volume. The column was maintained at $40^{\circ} \mathrm{C}$ and detection was carried out at $280 \mathrm{~nm}$.

\subsection{Method validation}

Validation of the analytical methods included the determination of method specificity, linearity, accuracy, precision, detection limit (LOD) and quantification limit (LOQ) according to $\mathrm{ICH}$ guideline [27]. An assessment of method robustness [28] was also performed using $2^{3}$ CCC DoE.

\section{RESULTS AND DISCUSSION}

Two HILIC methods were developed for simultaneous determination of the major alkaloids (MO, CD, TB, OR, PV and NS) present in Papaver somniferum L. (Papaveraceae) straw (cultivated in the Republic of Macedonia). The chromatographic behavior of target alkaloids was investigated on two different HILIC stationary phases, bare silica (Si-HILIC) and zwitterionic (ZIC-HILIC).

DoE was employed for determining the relationships between chromatographic conditions $(\mathrm{pH}$ value and ionic strength of the mobile phase buffer, ACN content in mobile phase and column temperature) and retention behavior of the analytes (through critical resolutions and relevant retention factors).

\subsection{Development and optimization of the Si-HILIC method}

Si-HILIC method was developed on a bare silica column, since it is the most commonly applied for the HILIC separations. Several different organic solvent mobile phase constituents (acetone, acetonitrile and methanol) were examined. Acetone gave high base-line noise (chromatograms not shown) and methanol did not separate critical analyte pairs, even under mildly chromatographic conditions. ACN was selected to be the organic solvent in the mobile phase and ammonium acetate was used as the mobile phase buffer.

Systematic optimization of the method was carried out by chemometrics. During the initial optimization of the Si-HILIC method, which involved a set of 11 screening experiments $\left(2^{3}\right.$ FFL
DoE, Table 1, Equation 1), the relationship between chromatographic conditions and retention behavior of the analytes was determined (Table 4). Initially, three experimental factors $\left(x_{1}, x_{2}\right.$ and $\left.x_{3}\right)$ were investigated: content of organic solvent in the mobile phase $\left(x_{1}\right)$ (75 to $\left.95 \%(\mathrm{v} / \mathrm{v}) \mathrm{ACN}\right)$, mobile phase buffer $\mathrm{pH}\left(x_{2}\right)$ (pH 2.0 to 4.0$)$ and ionic strength of the mobile phase buffer $\left(x_{3}\right)$ (5 to $25 \mathrm{mM}$ ammonium acetate).

The results of the first set of chemometric experiments showed that all factors had an impact on the chromatographic parameters. Critical resolution between NS and PV was perceived, taking into account that both components were eluted in the column void time $(0.9 \mathrm{~min})$. By increasing the proportion of $\mathrm{ACN}$ and lowering the $\mathrm{pH}$ of the buffer, NS/PV resolution was enhanced and the $k$ ' value for the last eluted peak (MO) was increased (exceeded 10, which was set as target maximum value). However, at low $\mathrm{pH}$, the NS/PV critical resolution was inconsistent, an undesirable effect in terms of robustness.

To further optimize experimental factors, another 11 experiments within the $2^{3}$ FFL DoE were applied (Table 1, Equation 1). The new ranges were 80 to $95 \%(\mathrm{v} / \mathrm{v}) \mathrm{ACN}\left(x_{1}\right), \mathrm{pH} 4.5$ to $6.5\left(x_{2}\right)$ and 75 to $125 \mathrm{mM}$ ammonium acetate $\left(x_{3}\right)$, based on screening experiments.

The retention behavior of the analytes was assessed through the critical resolution of NS and $\mathrm{PV}$ as well as the retention factors for MO and NS. The effects of the different chromatographic conditions on chromatographic descriptors are shown through the normalized DoE coefficients in Figure $1 \mathrm{~A}$, and the chromatographic descriptors over the defined area of the experimental factors assessed using RSM are shown in Figure 1B. Since mobile phase $\mathrm{pH}$ was the factor with the least impact on the chromatographic descriptors, this parameter was kept constant at 4.5 for presentation purposes in the contour diagram.

The factor coefficients within this design (Figure 1A) were similar to those in the first set of experiments. By increasing ionic strength, the resolution between NS and PV was increased and $k^{\prime}$ value of NS decreased. RSM results (Figure 1B) revealed satisfactory NS/PV resolution of 1.5 within the $\mathrm{pH}$ range, but only when the largest proportion of $\mathrm{ACN}$ and highest buffer ion strength was used. On the other hand, the $k^{\prime}$ value of the last eluted (MO) peak (target value in the range from 1 to 10 , for any peak) was affected most by $\mathrm{ACN}$ content in the mobile phase, and was satisfactory at high ionic buffer strength and ACN content below $85 \%$ for all $\mathrm{pH}$ values. 
T a ble 4

Experimental data for assessment of the chromatographic response during the Si-HILIC initial method development

\begin{tabular}{ccccccc}
\hline \hline $\begin{array}{c}\text { Experi- } \\
\text { ment }\end{array}$ & $\begin{array}{c}x_{1} \\
(\%(V / V) \mathrm{ACN})\end{array}$ & $\begin{array}{c}x_{2} \\
(\mathrm{pH})\end{array}$ & $\begin{array}{c}x_{3} \\
(\mathrm{mM})\end{array}$ & $\begin{array}{c}\text { Rs } \\
(\mathrm{NS} / \mathrm{PV})\end{array}$ & $\begin{array}{c}k^{\prime} \\
(\mathrm{NS})\end{array}$ & $\begin{array}{c}k^{\prime} \\
(\mathrm{MO})\end{array}$ \\
\hline N1 & 75 & 2.0 & 5 & 0.0 & 1.9 & 3.3 \\
N2 & 95 & 2.0 & 5 & 0.7 & 6.1 & $>35$ \\
N3 & 75 & 4.0 & 5 & 0.0 & 0.3 & 5.4 \\
N4 & 95 & 4.0 & 5 & 1.5 & 0.5 & 34.2 \\
N5 & 75 & 2.0 & 25 & 0.0 & 1.3 & 2.7 \\
N6 & 95 & 2.0 & 25 & $/$ & 0.5 & $>35$ \\
N7 & 75 & 4.0 & 25 & 0.0 & 0.3 & 4.1 \\
N8 & 95 & 4.0 & 25 & 1.6 & 0.5 & $>35$ \\
N9 & 85 & 3.0 & 15 & 0.0 & 0.5 & 8.4 \\
N10 & 85 & 3.0 & 15 & 0.0 & 0.5 & 8.4 \\
N11 & 85 & 3.0 & 15 & 0.0 & 0.5 & 8.4 \\
\hline \hline
\end{tabular}

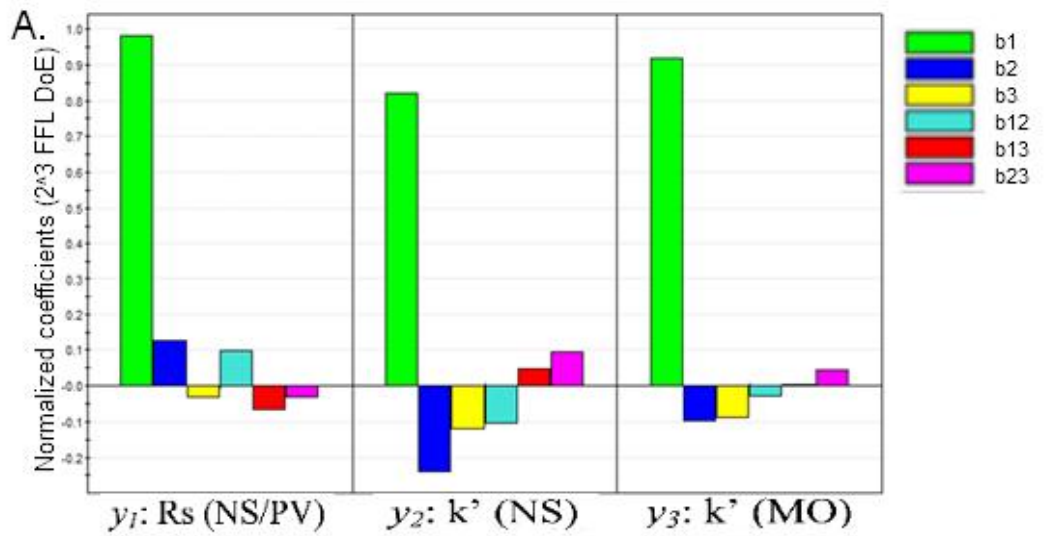

B.
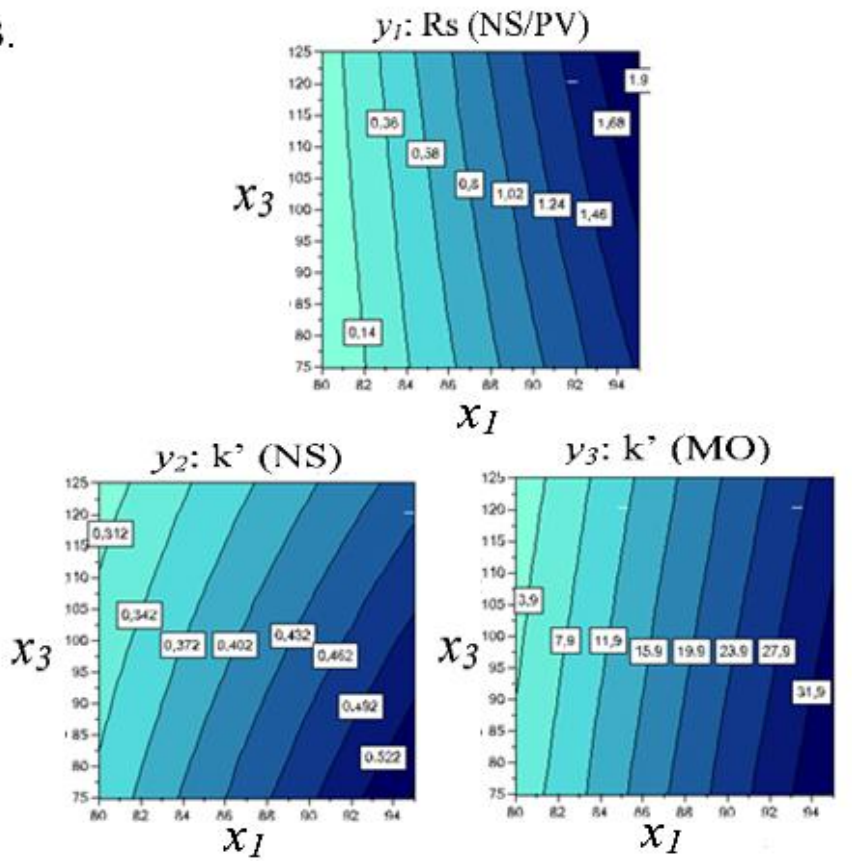

Fig. 1. Development and final optimization of the Si-HILIC method by use of chemometrics

A. Normalized coefficients of the $2^{3}$ FFL DoE showing the effects of different chromatographic conditions: $b_{1}$ (ACN content), $b_{2}$ ( $\mathrm{pH}$ value of the mobile phase buffer), $b_{3}$ (ionic strength of the mobile phase buffer) and their interactions $\left(b_{12}, b_{13}, b_{23}\right)$ on the chromatographic descriptors (resolution between critical pairs of analytes and retention factors of the first and last eluting peaks) during the final Si-HILIC method optimization. B. Contour diagram of the: influence of the change of the ACN content $\left(x_{1}\right)$ and ionic strength of the mobile phase buffer $\left(x_{3}\right)$ with the constant $\mathrm{pH}$ value of 4.5 for the mobile phase buffer ( $x_{2}$ at low level), on the critical resolution NS/PV $\left(y_{1}\right)$, retention factor of NS $\left(y_{2}\right)$ and retention factor of $\mathrm{MO}\left(y_{3}\right)$. 
Isocratic elution was unsatisfactory, as the critical resolution between NS and PV (presumably due to large differences between their $p K a$ values and the amphoteric properties of $\mathrm{MO}, \mathrm{CO}$ and $\mathrm{OR}$ ) for all investigated chromatographic conditions was below 1.5 , and the retention factor of NS was unsatisfactory (eluted within the dead volume of the column) for any combination of experimental conditions. Since isocratic elution of the six alkaloids was inapplicable, a gradient elution was employed.

Gradient steps were predicted from chemometric assessment of experimental data. Satisfactory resolution (Rs of 1.5) for the first two peaks (NS and PV) was obtained using high ionic strength buffer $(125 \mathrm{mM})$ at $\mathrm{pH} 4.5$. The last peak (MO) eluted with a satisfactory factor retention in $85 \% \mathrm{ACN}$, regardless of the aqueous portion in the mobile phase. A gradient was established starting with an isocratic step of $95 \%$ ACN for one minute to obtain suitable separation of NS and PV and a subsequent seven minute isocratic step using $85 \%$ ACN (experimental region where retention factor of MO was suitable, Figure 1). A 20 minute period using the initial conditions was used for column reequilibration. Despite the short separation time (less than 10 min, Figure 2), gradient elution resulted in a long runtime (30 min total) due to the re-equilibration time for HILIC conditions.

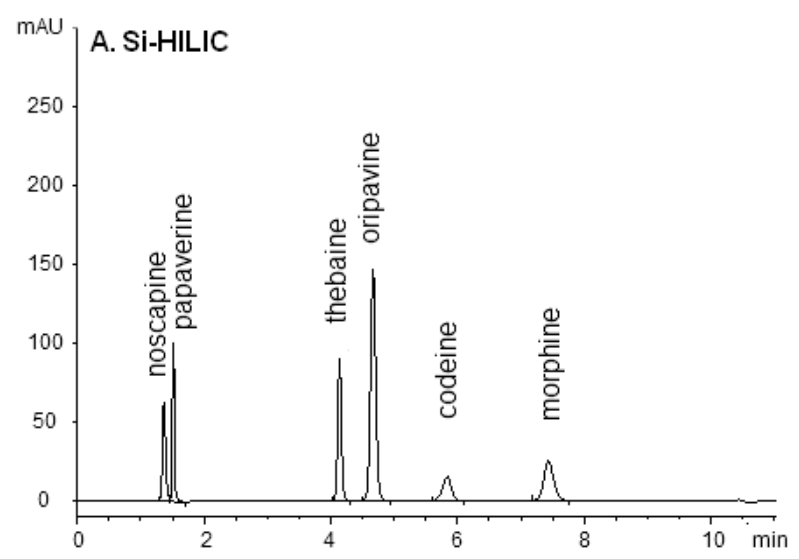

Fig. 2. Typical chromatograms of the Si-HILIC method: Bare silica column (Lichrospher Hibar Si, Merck, $250 \times 4.6 \mathrm{~mm}$, $5 \mu \mathrm{m})$; Gradient elution using ammonium acetate buffer (125 $\mathrm{mM}, \mathrm{pH} 4.5)$ and $\mathrm{ACN}(0-1 \mathrm{~min} 95 \%, 1.1-8 \mathrm{~min} 85 \%$, followed by equilibration step $8.1-30 \mathrm{~min} 95 \% \mathrm{v} / v \mathrm{ACN}$ ) as mobile phase at flow rate of $2.0 \mathrm{ml} / \mathrm{min}$; Injection volume: $20 \mu \mathrm{l}$; Column temperature: $30^{\circ} \mathrm{C}$; Detection: $280 \mathrm{~nm}$.

\subsection{Development and optimization of the ZIC-HILIC method}

Considering the fact that zwitterion stationary phases are designed for efficient HILIC sepa- ration of acidic, basic and neutral hydrophilic compounds [15], a ZIC HILIC column was chosen for further method development to obtain a simpler (isocratic) and faster method for alkaloid determinations. During the first set of 11 experiments used for chemometric optimization $\left(2^{3}\right.$ FFL DoE, Table 1, Equation 1), experimental factors were: 75 to 95 $\%(v / v) \operatorname{ACN}\left(x_{1}\right), 15$ to $125 \mathrm{mM}$ ammonium acetate $\left(x_{2}\right)$ and a $\mathrm{pH}$ of value 4.0 to $7.0\left(x_{3}\right)$. Retention behavior of the analytes was assessed through the critical resolutions (NS/PV, OR/TB and CD/MO) and the retention factors of MO and NS. The effects of the different chromatographic conditions on the defined chromatographic descriptors are shown through the normalized DoE coefficients (Figure 3). The data indicated all factors had an impact on the retention and separation of the compounds, similar to the Si-HILIC method. NS and PV eluted within the void time of the column (1 min), consequently the critical resolution between them persisted.

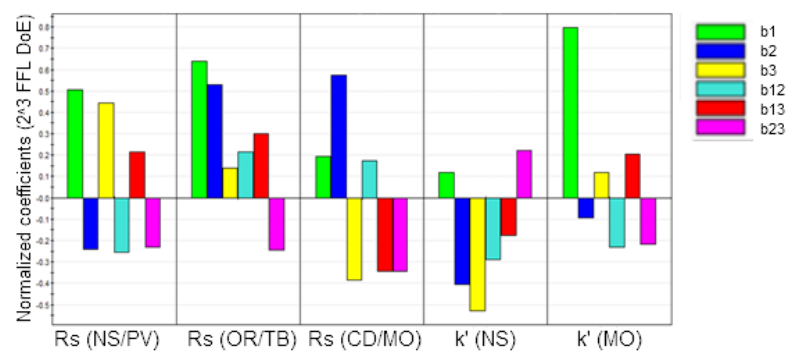

Fig 3. Normalized coefficients of the $2^{3}$ FFL DoE showing the effects of different chromatographic conditions: $b_{1}-\mathrm{ACN}$ content, $b_{2}$-ionic strength of the mobile phase buffer, $b_{3}-\mathrm{pH}$ value of the mobile phase buffer, and their interactions $\left(b_{12}\right.$, $b_{13}, b_{23}$ ) on the chromatographic descriptors (resolution between NS/PV $\left(y_{1}\right)$, OR/TB $\left(y_{2}\right), \mathrm{CD} / \mathrm{MO}\left(y_{3}\right)$ and retention factors of MO $\left(y_{4}\right)$ and NS $\left.\left(y_{5}\right)\right)$ during the initial ZIC-HILIC method optimization

The second part of the ZIC-HILIC method development was focused on the differences between the alkaloid polarities, the amphoteric properties of some of MO, CO and OR as well as the limited water solubility of NS and PV. The chromatographic behaviour of analytes was investigated at different mobile phase $\mathrm{pH}$ values (3-8) to obtain a $\mathrm{pH}$ profile for components in the mixture. This was determined by two independent $2^{2}$ CCC DoEs with basic and acidic mobile phases (Equation 2), where each set included 11 planned experiments (Table 2) investigating $\mathrm{pH}\left(x_{1}\right)(3.0-5.0$ for the acidic profile and 6.0-8.0 for the basic profile) and ionic strength of the mobile phase buffer $\left(x_{2}\right)$ (10-100 $\mathrm{mM}$ ammonium formate buffer for the acidic profile and $10-100 \mathrm{mM}$ ammonium ace- 
tate for the basic profile). The chromatographic response was assessed by evaluating the critical resolution of NS/PV and the retention factor of
MO, and alterations in chromatographic descriptors over the defined area of the experimental factors were assessed using RSM (Figure 4).
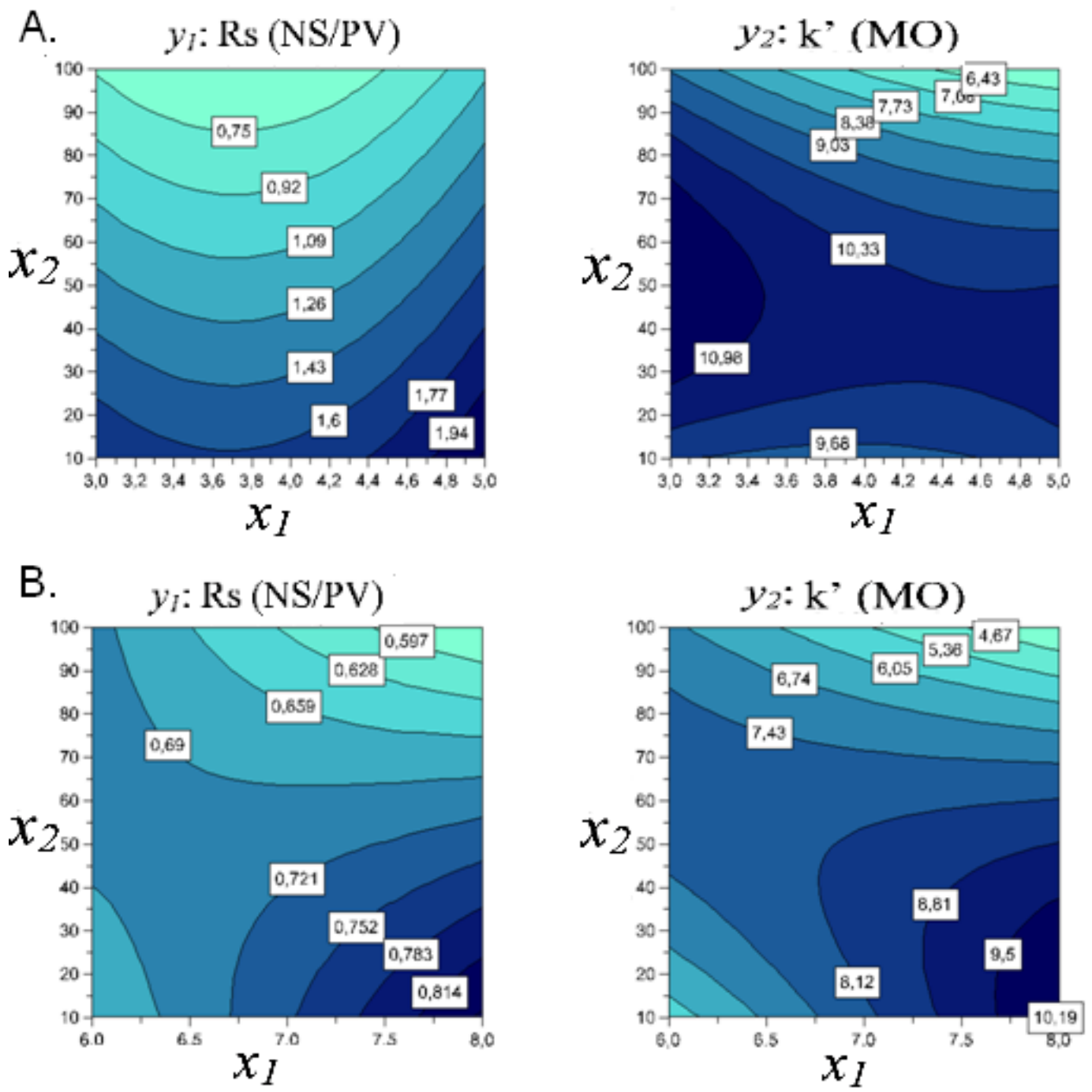

Fig. 4. Contour diagram of the: influence of the change of the $\mathrm{pH}$ value $\left(x_{1}\right)$ and the ionic strength of the mobile phase buffer $\left(x_{2}\right)$, with the constant flow of $1.0 \mathrm{ml} / \mathrm{min}$ and constant ACN content (90\%), on the critical resolution $\left(y_{1}\right)$ and retention factor of MO $\left(y_{2}\right)$

in acidic (A) and basic (B) $\mathrm{pH}$ range of the buffer during the optimization of the ZIC-HILIC method by use of chemometrics

Although a zwitterionic stationary phase should be able to separate compounds with different polarities [15], satisfactory system suitability criteria under isocratic conditions were not achieved. This was attributed to the insolubility of NS and PV in water, as ZIC-HILIC selectivity had poor resolution power for these compounds (eluted together with the void volume of the column).

Based on this observation, gradient elution was defined by the evaluation of chemometric data for the influence of factors and the $\mathrm{pH}$ profile of components in the mixture. Satisfactory resolution (Rs of 1.6) for the first two peaks (NS and PV) was obtained using buffer with the lowest ionic strength $(10 \mathrm{mM})$ at $\mathrm{pH}$ 4.0. The last peak (MO) was eluted with satisfactory factor retention in $80 \%$ ACN, regardless of the characteristics of the aqueous portion of the mobile phase. The gradient started with an isocratic $95 \%$ ACN step for two minutes to separate $\mathrm{NS}$ and $\mathrm{PV}$, then eight minute isocratic step using $80 \% \mathrm{ACN}$ (experimental region where retention factor of MO was suitable, Figure 4) and a column re-equilibration of $20 \mathrm{~min}$ utes. Separation was obtained within 8 minutes (Figure 5), but total analysis time was 30 minutes (including the re-equilibration). 


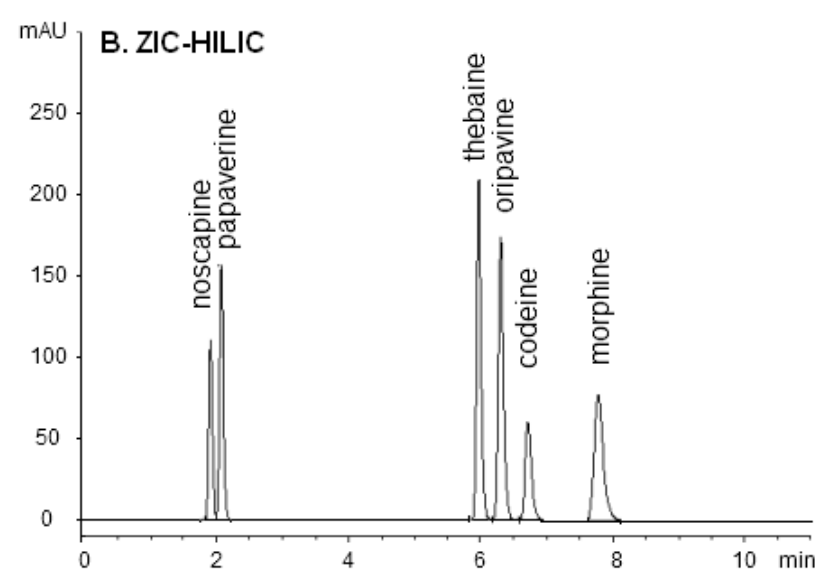

Fig. 5. Typical chromatograms of the ZIC-HILIC method. Zwitterionic stationary phase (SeQuant ${ }^{\mathbb{B}}$ ZIC $^{\circledR}$-HILIC column, Merck, $150 \times 4.6 \mathrm{~mm}, 5 \mu \mathrm{m})$; Gradient elution using ammonium formate buffer (10 mM, pH 4.0) and ACN (0-2 min 95\%; 2.1-10 $\min 80 \%$, followed by equilibration step: $10.1-30 \mathrm{~min} 95 \% \mathrm{v} / \mathrm{v}$

$\mathrm{ACN}$ ) as mobile phase at flow rate of $1.0 \mathrm{ml} / \mathrm{min}$; Injection volume: $20 \mu \mathrm{l}$; Column temperature: $40^{\circ} \mathrm{C}$; Detection: $280 \mathrm{~nm}$.

\subsection{Validation of the methods}

The separation of all compounds was obtained within a close retention window with optimized gradient elution on bare silica (Figure 2) and zwitterionic stationary phases (Figure 5). Validation of the two HILIC methods (Table 5) showed satisfactory specificity, linearity, sensitivity, accuracy, precision and reproducibility for the tested alkaloids.

\subsection{Robustness testing}

Determination of analytical method robustness during validation $[35,36]$ requires extensive experimental work, where defined changes in experimental conditions are made. By performing a set of 17 experiments (Table 3 ) defined by the $2^{3}$ CCC DoE (Equation 3) where small changes in experimental factors values (determined as critical during method optimization) were made, a rational assessment of the method robustness was achieved (Figure 6).

\section{T a ble 5}

Results obtained from testing different parameters during validation of the Si-HILIC and ZIC-HILIC method

\begin{tabular}{|c|c|c|c|c|c|c|}
\hline Parameter & $\begin{array}{l}\text { Noscapine } \\
\quad \text { (NS) }\end{array}$ & $\begin{array}{l}\text { Papaverine } \\
\text { (PV) }\end{array}$ & $\begin{array}{l}\text { Thebaine } \\
\text { (TB) }\end{array}$ & $\begin{array}{l}\text { Oripavine } \\
\quad(\mathrm{OR})\end{array}$ & $\begin{array}{l}\text { Codeine } \\
\text { (CD) }\end{array}$ & $\begin{array}{l}\text { Morphine } \\
\text { (MO) }\end{array}$ \\
\hline System suitability & \multicolumn{6}{|c|}{ Si-HILIC method } \\
\hline Retention factor $\left(k^{\prime}\right)$ & 0.5 & 0.6 & 3.4 & 4.0 & 5.2 & 6.9 \\
\hline Number of theoretical plates $(N)$ & 3688 & 7417 & 24252 & 15645 & 9186 & 11704 \\
\hline Resolution $(R \mathrm{~s})$ & I & 1.9 & 29.7 & 4.2 & 6.0 & 6.1 \\
\hline Linearity $\left(R^{2}\right)$ & 0.9999 & 0.9986 & 1.0000 & 1.0000 & 1.0000 & 1.0000 \\
\hline $\begin{array}{l}\text { Conc. range }(\mu \mathrm{g} / \mathrm{ml}) \\
\text { Sensitivity }\end{array}$ & $25-150$ & $12.5-75$ & $12.5-75$ & $12.5-75$ & $25-150$ & $50-300$ \\
\hline $\mathbf{L O D}(\mu \mathrm{g} / \mathrm{ml})$ & 0.60 & 0.32 & 0.35 & 0.33 & 0.58 & 1.10 \\
\hline $\begin{array}{l}\mathbf{L O Q}(\mu \mathrm{g} / \mathrm{ml}) \\
\text { Accuracy }\end{array}$ & 1.98 & 1.06 & 1.16 & 1.10 & 1.93 & 3.66 \\
\hline $\begin{array}{l}\text { Recovery }(\%, n=3) \text { on } 100 \% \text { of } \\
\text { working concentration }\end{array}$ & I & $(99.6 \pm 1.1)$ & $(99.4 \pm 2.3)$ & $(100.6 \pm 1.8)$ & $(99.8 \pm 1.1)$ & $(99.9 \pm 1.4)$ \\
\hline System suitability & \multicolumn{6}{|c|}{ ZIC-HILIC method } \\
\hline Retention factor $\left(k^{\prime}\right)$ & 0.9 & 1.1 & 5.0 & 5.3 & 5.7 & 6.8 \\
\hline Number of theoretical plates $(N)$ & 5614 & 5982 & 38369 & 32330 & 24233 & 16114 \\
\hline Resolution $(R \mathrm{~s})$ & / & 1.9 & 33.2 & 2.5 & 2.6 & 5.1 \\
\hline Linearity $\left(R^{2}\right)$ & 1.0000 & 1.0000 & 0.9998 & 0.9999 & 0.9998 & 1.0000 \\
\hline Conc. range $(\mu \mathrm{g} / \mathrm{ml})$ & $25-150$ & $12.5-75$ & $12.5-75$ & $12.5-75$ & $25-150$ & $50-300$ \\
\hline \multicolumn{7}{|l|}{ Sensitivity } \\
\hline LOD $(\mu \mathrm{g} / \mathrm{ml})$ & 0.57 & 0.30 & 0.31 & 0.30 & 0.60 & 1.07 \\
\hline $\mathbf{L O Q}(\mu \mathrm{g} / \mathrm{ml})$ & 1.73 & 0.91 & 0.93 & 0.90 & 1.80 & 3.24 \\
\hline \multicolumn{7}{|l|}{ Accuracy } \\
\hline $\begin{array}{l}\text { Recovery }(\%, n=3) \text { on } 100 \% \text { of } \\
\text { working concentration }\end{array}$ & $(99.6 \pm 1.4)$ & $(99.3 \pm 1.2)$ & $(99.8 \pm 0.9)$ & $(99.7 \pm 0.8)$ & $(100.1 \pm 1.0)$ & $(99.9 \pm 0.6)$ \\
\hline
\end{tabular}

(i) $\quad \mathrm{P}(95 \%$ confidence interval)

(ii) Working concentration for NS: $100 \mu \mathrm{g} / \mathrm{ml}, \mathrm{PV}: 50 \mu \mathrm{g} / \mathrm{ml}, \mathrm{TB}: 50 \mu \mathrm{g} / \mathrm{ml}, \mathrm{OR}: 50 \mu \mathrm{g} / \mathrm{ml}, \mathrm{CD}: 100 \mu \mathrm{g} / \mathrm{ml}$ and MO: $200 \mu \mathrm{g} / \mathrm{ml}$ 
The results obtained from the robustness testing of the Si-HILIC method (Figure 6A) indicated that small changes in temperature $\left( \pm 5^{\circ} \mathrm{C}\right)$, $\mathrm{pH}$ of the mobile phase $( \pm 0.1)$ and the content of the organic solvent in the mobile phase $( \pm 2 \%$ $\mathrm{ACN}$ ), did not change retention of MO and NS significantly, but this was not quite the case with the NS/PV resolution. The defined resolution value was not achieved when ACN exceed $95 \%$ and a
$\mathrm{pH}$ diminished 4.5, especially when the experimental factors were changed simultaneously.

The ZIC-HILIC method proved robust for all variations (Figure 6B). The critical resolution between NS and PV remained above 1.5 with greater changes in temperature $\left( \pm 5^{\circ} \mathrm{C}\right), \mathrm{pH}$ of the mobile phase $( \pm 0.5)$ and the content of organic solvent in the mobile phase $( \pm 2 \% \mathrm{ACN})$.
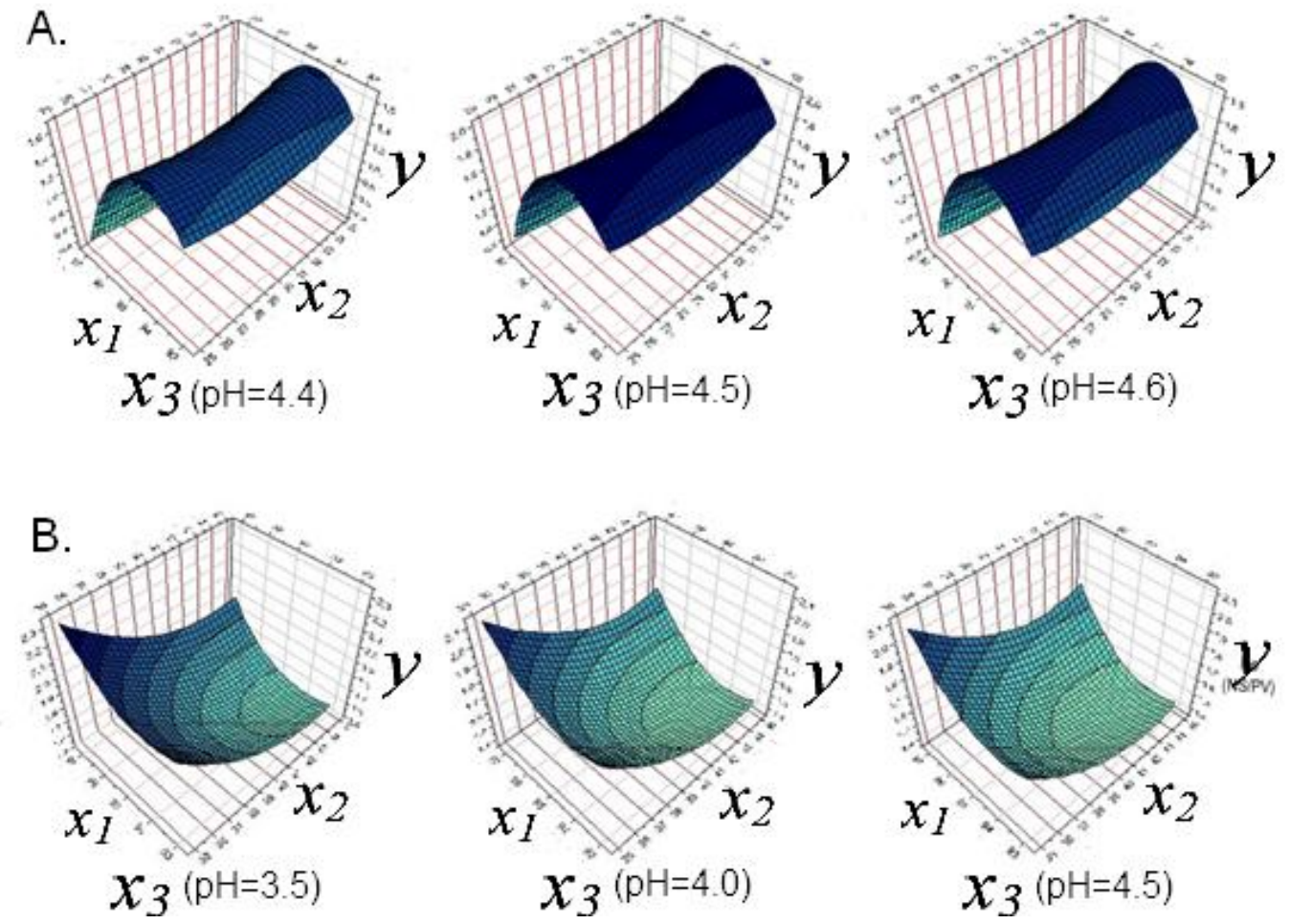

Fig. 6. Results obtained from testing the robustness of the Si-HILIC and ZIC-HILIC methods $\left(2^{3}\right.$ CCC DoE)

A. The effects of changes in different analytical conditions during the robustness testing of the Si-HILIC method: $x_{1}-$ column temperature $\left(25-35^{\circ} \mathrm{C}\right), x_{2}-\mathrm{pH}$ of the mobile phase $(4.4-4.6)$ and $x_{3}-$ the mobile phase organic solvent $(93-97 \% \mathrm{ACN})$ on the chromatographic response: $y$ - critical resolution. B. The effects of changes in different analytical conditions during the robustness testing of the ZIC-HILIC method: $x_{1}-$ column temperature $\left(35-45^{\circ} \mathrm{C}\right), x_{2}-\mathrm{pH}$ of the mobile phase $(3.5-4.5)$ and $x_{3}-$ the mobile phase organic solvent $(93-97 \% \mathrm{ACN})$ on the chromatographic response: $y$ - critical resolution.

\subsection{Summary of characteristics of the proposed methods}

The results from the systematic optimization of the two HILIC methods by chemometrics revealed that all examined factors had an impact on retention and separation of opium poppy alkaloids, but also some limitations in terms of system suitability criteria, presumably due to the large differences between $p K a$ values, amphoteric properties of $\mathrm{MO}, \mathrm{CO}$ and OR and hydrophobicity of NS and PV.

For separation of all six alkaloids, gradient elution was necessary, which despite a short separation time (within $10 \mathrm{~min}$ ), required a long run- time (of total $30 \mathrm{~min}$ ) due to the prolonged reequilibration time needed for HILIC.

The Si-HILIC method showed limited robustness in terms of $\mathrm{ACN}$ content and $\mathrm{pH}$ of the mobile phase buffer, which disables easy interlaboratory transfer of the method. Furthermore, this method could not be used hyphenated with MS, as the ionic strength of the ammonium acetate buffer $(125 \mathrm{mM})$ was above the recommended maximum $(20 \mathrm{mM})$.

ZIC-HILIC separation was achieved within 8 minutes, with a total run-time of 30 minutes due to the re-equilibration of the column. The retention factor for NS was acceptable in terms of system 
suitability criteria and this method proved robust over a wider range of experimental conditions. Additionally, a mobile phase composition (ACN/10mM formate buffer) allowed combination with MS.

Both methods were suitable for determination only of morphinan alkaloids (MO, CD, OR and TB) in poppy straw, crucial for the applicability of the methods. ZIC-HILIC required half the mobile phase flow rate of Si-HILIC, which when taking into account $\mathrm{ACN}$ price and disposal issues, reduced the direct costs of the method. The method developed using a zwitterionic stationary phase (ZIC-HILIC method) allowed for the characterization of the opium poppy samples generated in a poppy selection program.

Acknowledgements. A part of this study was financially supported by ALKALOID A.D. Skopje.

Abbreviations: HILIC - Hydrophilic interaction liquid chromatography; Si-HILIC method - Hydrophilic interaction liquid chromatography method on a bare silica column; ZIC-HILIC method - Hydrophilic interaction liquid chromatography method on a column with zwitterionic stationary phase; RP-HPLC - reverse phase high pressure liquid chromatography; MS - mass spectrometry; Rs - Resolution; DoE Design of experiments; RSM - Response Surface Methodology; FFL DoE - Full Factorial Linear Design of Experiment; CCC DoE - Central Composite Circumscribed Design of Experiments; $\mathrm{MO}$ - Morphine; CD - Codeine; OR - Oripavine; TB - Thebaine; PV - Papaverine; NS - Noscapine; ACN acetonitrile.

\section{REFERENCES}

[1] International Narcotics Control Board Technical report 2011 and estimated world requirements for 2012 Statistics for 2010, United Nations Publication, 2012.

[2] A. Gümüoçü, N. Arslan, E. O. SarBhan, Evaluation of selected poppy (Papaver somniferum L.) lines by their morphine and other alkaloids contents, Eur Food Res Technol., 226, 1213-1220 (2008).

[3] S. Frick, R. Kramell, J. Schmidt, A. J. Fist, T. M. Kutchan, Comparative Qualitative and Quantitative Determination of Alkaloids in Narcotic and Condiment $\mathrm{Pa}$ paver somniferum Cultivars, J Nat Prod., 68, 666-673 (2005).

[4] Z. Szucs, B. Szabady, M. Szatmáry, G. Cimpan \& Sz. Nyiredy, High-throughput analytical strategy with combined planar and column liquid chromatography for improvement of the poppy (Papaver somniferum L.) with a high alkaloid content, Chromatographia, 56, S49-S54 (2002).

[5] M. Anyzewska, E. Wojtasik, I. Arent, The development and validation of the HPLC method for morphine content determination in poppy straw, Acta Pol Pharm Drug research, 58, 121-126 (2001).

[6] M. Espinosa Bosch, A. Ruiz Sanchez, F. Sanchez Rojas, C. Bosch Ojeda, Morphine and its metabolites: Analytical methodologies for its determination, J Pharmaceut Biomed Anal., 43, 799-815 (2007).
[7] S. Honoré Hansen, Sample preparation and separation techniques for bioanalysis of morphine and related substances, J Separ Sci, 32, 825 - 834 (2009).

[8] R. Dams, T. Benijts, W. E. Lambert, A. P. De Leenheer, Simultaneous determination of in total 17 opium alkaloids and opioids in blood and urine by fast liquid chromatography - diode array detection-fluorescence detection, after solid-phase extraction, J Chrom B., 773, 5361 (2002).

[9] C. Sproll, R. C. Perz, D. W. Lachenmeier, Highperformance liquid chromatographic assay for morphine in small plasma samples: application to pharmacokinetic studies in rats, J Agric Food Chem., 54, 5292 (2006).

[10] H. A. Claessens, Trends and progress in the characterization of stationary phases for reversed-phase liquid chromatography, Trends in Analytical Chemistry, 20, 563-583 (2001).

[11] M. Cooke, C. F. Poole, I. D. Wilson, E. R. Adlard, Encyclopedia of separation science, Academic Press, 2000.

[12] J. Acevska, G. Stefkov, R, Petkovska, S. Kulevanova, A. Dimitrovska, Chemometric approach for development, optimization and validation of different chromatographic methods for separation of opium alkaloids, Anal Bioanal Chem., 403, 1117-1129 (2012).

[13] J. Acevska, A. Dimitrovska, G. Stefkov, K. Brezovska, M. Karapandzova, S. Kulevanova, Development and validation of RP-HPLC method for determination of alkaloids from Papaver somniferum L., Papaveraceae, $J$ AOAC Int., 95, 399-405 (2012).

[14] R. Li, Y. Zhanga, C. C. Leeb, R. Lua, Y. Huanga, Development and validation of a hydrophilic interaction liquid chromatographic method for determination of aromatic amines in environmental water, J Chrom A, 1217, 1799-1805 (2010).

[15] W. Jiang, G. Fischer, Y. Girmay, K. Irguma, Zwitterionic stationary phase with covalently bonded phosphorylcholine type polymer grafts and its applicability to separation of peptides in the hydrophilic interaction liquid chromatography mode, J Chrom A, 1127, 82-91 (2006).

[16] V. V. Tolstikov, O. Fiehn, Analysis of Highly Polar Compounds of Plant Origin: Combination of Hydrophilic Interaction Chromatography and Electrospray Ion Trap Mass Spectrometry, Anal Biochem., 301, 298-307 (2002).

[17] E. S. Grumbach, D. M. Wagrowski-Diehl, J. R. Mazzeo, B. Alden, P. C. Iraneta, Hydrophilic Interaction Chromatography Using Silica Columns for the Retention of Polar Analytes and Enhanced ESI-MS Sensitivity, LCGC Notrh America, 22, 1010-1023 (2004).

[18] G. A. Leweis, D. Mathieu, R. Phan-Tan-Luu, Pharmaceutical experimental design, New York: Marcel Decker, 1999.

[19] R. L. Mason, R. F. Gunst, J. L. Hess, Statistical Design and Analysis of Experiments, 2nd edn., New Jersey: Wiley, 2003.

[20] S. N. Deming, S. L. Morgan, Experimental Design: A Chemometric Approach, 2nd edn., New York: Elsevier Sci. Publishing, 1993.

[21] T. Lundstedt, E. Seifert, L. Abramo, B. Thelin, A. Nystrom, J. Oettersen, R. Bergman, Experimental design and optimization, Chemom Intell Lab Syst., 42, 3-40 (1998). 
[22] D. C. Montgomery, Design and Analysis of Experiments, New Jersey: John Wiley\&Sons Inc., 1976.

[23] M. A. Sharaf, D. L. Illman, Chemometrics, New York: Wiley, 1986.

[24] D. L. Massart, B. G. M. Vandeginste, S. N. Deming, Y. Michotte, L. Kaufman, Chemometrics: A Textbook, New York: Elsevier Sci. Publishing Company inc., 1998.

[25] R. G. Brereton, Chemometrics - Data Analysis for the Laboratory and Chemical Plant, The Atrium, Chichester, England, John Wiley \& Sons Ltd., 2003.
[26] http://www.umetrics.com/products/modde.

[27] ICH on Technical Requirements for Registration of Pharmaceuticals for Human Use, Guideline on Validation of Analytical Procedures: Text and methodology Q2(R1), Harmonized Tripartite Guideline, Switzerland, 2005.

[28] B. Dejagher, X. Carpon, J. Smeyers-Verbeke, Y. Vander Heyden, Randomization tests to identify significant effects in designs for robustness testing, Anal Chim Acta, 564, 184-200 (2006). 